\title{
Carcass and meat characteristics of different cattle categories fed diets containing crude glycerin
}

\section{Características de carcaça e da carne de diferentes categorias de bovinos alimentados com dietas contendo glicerina bruta}

\author{
Jean Pacheco Leão ${ }^{1}$; Jose Neuman Miranda Neiva ${ }^{2 *}$;oão Restle ${ }^{3}$; Regis Luis \\ Míssio $;$; Pedro Veiga Rodrigues Paulino5; Fabricia Rocha Chaves Miotto²; Aline \\ Evangelista Machado Santana ${ }^{6}$; Luciano Fernandes Sousa ${ }^{2}$; Emerson Alexandrino ${ }^{2}$
}

\begin{abstract}
The objective of the present study was to assess the carcass and meat characteristics of cows and castrated crossbred steer from dairy breeds fed in a feedlot with different levels of crude glycerin in the diet. Twenty-four animals were used, 12 cows with $467 \pm 15 \mathrm{~kg}$ initial bodyweight and 12 steer $347 \pm$ $17 \mathrm{~kg}$ initial bodyweight. A complete randomized design in a 4 x 2 factorial arrangement (four crude glycerin levels and two animal categories) was used. The crude glycerin levels were 0, 60, 120 and 240 $\mathrm{g} / \mathrm{kg}$ in dry matter diet, formulated with $800 \mathrm{~g}$ concentrate/kg dry matter. Including crude glycerin in the diet did not alter carcass weight and yield, backfat thickness and meat qualitative characteristics. Cows presented heavier hot carcass (279.4 versus $231.8 \mathrm{~kg}$ ) with greater backfat thickness ( 3.8 versus 5.2 $\mathrm{mm}$ ) than steer. Crude glycerin in quantities from 0 and $120 \mathrm{~g} / \mathrm{kg}$ dry matter diet resulted in less muscle and greater fat participation in the cow carcass compared to the steer carcass. The cow meat was darker in coloring and had a higher degree of marbling than the steer. There was no difference for tenderness or total liquid losses during meat thawing and cooking between cows and steer. Crude glycerin can be added up to $240 \mathrm{~g} / \mathrm{kg}$ diet dry matter for cows and steer from dairy breeds, because it does not decrease the quality of the carcass or the meat produced.
\end{abstract}

Key words: Biodiesel, biofuel, tenderness, marbling, byproducts, cows

\section{Resumo}

Objetivou-se avaliar as características de carcaça e carne de vacas de descarte e novilhos castrados mestiços de raças de aptidão leiteira alimentados em confinamento com diferentes níveis de glicerina bruta na dieta. Foram utilizados 24 animais, sendo 12 vacas de descarte com peso corporal inicial de $467 \pm 15 \mathrm{~kg}$ e 12 novilhos com peso corporal inicial de $347 \pm 17 \mathrm{~kg}$. O delineamento experimental foi o inteiramente casualizado, com os tratamentos em arranjo fatorial $4 \times 2$ (quatro níveis de glicerina bruta e duas categorias animal). Os níveis de glicerina testados foram de 0,60,120 e $240 \mathrm{~g} / \mathrm{kg}$ de matéria seca de dietas formuladas com $800 \mathrm{~g}$ de concentrado/kg de matéria seca. A inclusão de glicerina bruta na dieta não alterou o peso e o rendimento de carcaça, a espessura de gordura subcutânea e as características qualitativas da carne. Vacas apresentaram carcaças quentes mais pesadas $(279,4 \mathrm{vs} .231,8 \mathrm{~kg})$ e com

\footnotetext{
Técnico da EJEPLAN, Araguaína, TO. E-mail jleao.vet@hotmail.com

2 Profs. da Escola de Medicina Veterinária e Zootecnia, Araguaína, TO. E-mail: araguaia2007@gmail.com; fabriciarchaves@, hotmail.com; luijank@hotmail.com; e_alexandrino@yahoo.com.br

3 Prof. Visitante Nacional Sênior da Escola de Medicina Veterinária e Zootecnia, Araguaína,TO. E mail: jorestle@terrra.com.br

4 Pós-Doutorando da Escola de Medicina Veterinária e Zootecnia, Araguaína, TO. E mail: regisluismissio@gmail.com

5 Prof. da Universidade Federal de Viçosa, UFV, Viçosa, MG. E mail: pveiga@ufv.br

6 Discente de Mestrado da Escola de Medicina Veterinária e Zootecnia, Araguaína, TO. E-mail: aline1machado@mail.uft.edu.br

* Author for correspondence
} 
maior espessura de gordura subcutânea (13,8 vs. 5,2 mm) que novilhos. A glicerina em quantidades de 0 e $120 \mathrm{~g} / \mathrm{kg}$ de matéria seca da dieta proporcionou menor participação de músculos e maior de gordura na carcaça de vacas em relação à carcaça de novilhos. A carne das vacas apresentou coloração mais escura e maior grau de marmoreio que novilhos. Não houve diferença para a maciez e nas perdas totais de líquidos durante descongelamento e cocção da carne entre vacas e novilhos. A glicerina pode ser adicionada em até $240 \mathrm{~g} / \mathrm{kg}$ de matéria seca da dieta de vacas de descarte e novilhos castrados mestiços de raças de aptidão leiteira, pois não diminui a qualidade da carcaça e da carne produzida.

Palavras-chave: Biodiesel, biocombustível, maciez, marmoreio, subprodutos, vacas

\section{Introduction}

A recent world concern is generating renewable energies and biodiesel appears as an important form to diversify the energy matrix of several countries in the world. Currently countries that are big fuel consumers, such as the United States, have begun to invest in biodiesel as an energy alternative with the perspective of producing 5 billion liters biodiesel in 2014 and Europe around 12 billion liters biodiesel. Assuming that for each 19 liters of biodiesel produced, 10 liters of crude glycerin are generated, it is estimated that in 2014 the United States will produce around 500 million liters crude glycerin and Europe something around 1.3 million liters crude glycerin.

Crude glycerin has been outstanding for use in animal feeding due to its energetic value that is similar to that of the corn grain (DONKIN, 2008). This aspect has triggered interest for its use in animal feeding because the cost of corn grain has increased due to demand for biofuel production.

Another interesting aspect is that crude glycerin is also a result of the biodiesel production process and is generated from vegetable oil transsterification. The offer of this byproduct has increased recently due to the incentive to produce fuels from renewable sources. Furthermore, supplying crude glycerin in animal feeding means that this byproduct is no longer pollute the environment and becomes a source of energy for animal protein production serving the requirements related to the sustainable animal production.

Although there are many studies on crude glycerin (MACH; BACH; DEVANT, 2009;
PARSONS; SHELOR; DROUILLARD， 2009; GOMES et al., 2011), little information has been generated regarding the effects of this byproduct on the carcass and meat characteristics of cows and steer of dairy breed origin. On the other hand, because of the differences associated to dry matter intake and tissue deposition in the carcass in different animal categories (NRC, 1996) and the carcass and meat characteristics of cows and steer (VAZ et al., 2002; KUSS et al., 2005; PASCOAL et al., 2009; VAZ et al., 2010), it has become important to assess the animal product generated by including crude glycerin in the diet.

Thus the objective of this study was to assess the carcass and meat characteristics of cows and steer from dairy breeds fed in a feedlot with crude glycerin levels in the diet.

\section{Material and Methods}

The experiment was carried out from December 12, 2009 to February 20, 2010 at the Federal University of Tocantins, Araguaína campus, located at $07^{\circ} 11^{\prime} 28^{\prime \prime}$ latitude south and $48^{\circ} 12^{\prime} 26^{\prime \prime}$ longitude west. The mean values for the maximum, minimum and mean temperatures, relative air humidity and rainfall during the experiment were $31.1^{\circ} \mathrm{C} ; 21.5^{\circ} \mathrm{C}$; $25.4^{\circ} \mathrm{C}, 86.0 \%$ and $303.3 \mathrm{~mm}$, respectively.

Twenty-four crossbred animals from dairy breeds, 12 contemporary culling cows approximately 60 months old, $467 \pm 15 \mathrm{~kg}$ initial bodyweight and 12 contemporary steer approximately 30 months old and $347 \pm 17 \mathrm{~kg}$ initial bodyweight, were used. A completely randomized design in a $4 \times 2$ factorial 
arrangement (four crude glycerin inclusion levels and two animal categories) with three replications, was used. Before the experimental period, the animals were identified, treated against ecto and endo parasites, supplemented with ADE vitamin complex and placed individually in covered stalls $\left(6 \mathrm{~m}^{2}\right)$ with cement floor, individual feeding trough and a drinker for every two animals.

The animals were distributed in treatments consisting of the experimental diets and were adapted to the diets and installations for 14 days and then confined for 84 days. Inclusions of 0,60 , 120 and $240 \mathrm{~g}$ of crude glycerin on dry matter diet were tested. The diets had $800 \mathrm{~g}$ concentrate/kg dry matter. Elephant grass silage was used as roughage and the food was supplied freely every day. Due to the presence of chlorides in the crude glycerin, the quantity of $\mathrm{NaCl}$ in the diets was corrected using two types of mineral mixture (Table 1).

Table 1. Centesimal composition of the experimental diets.

\begin{tabular}{lllll}
\hline \multirow{2}{*}{ Ingredients $(\mathrm{g} / \mathrm{kg}$ dry matter) } & \multicolumn{4}{l}{ Crude glycerin in the diet $(\mathrm{g} / \mathrm{kg}$ dry matter $)$} \\
\cline { 2 - 5 } & 0 & 60 & 120 & 240 \\
\hline Elephant grass silage & 200.0 & 200.0 & 200.0 & 200.0 \\
Soybean meal & 110.5 & 110.0 & 110.0 & 110.0 \\
Corn kernels & 663.8 & 611.4 & 550.0 & 427.3 \\
Crude glycerin & 0.0 & 60.0 & 120.0 & 240.0 \\
Urea & 0.0 & 1.0 & 3.9 & 8.0 \\
Calcitic calcium & 5.7 & 6.8 & 6.1 & 4.7 \\
Mineral mixture & $20.0^{*}$ & $10.0^{* *}$ & $10.0^{* *}$ & $10.0^{* *}$ \\
\hline
\end{tabular}

*Composition (in1000g): Na: 140 g; Ca: 151 g; P: 85 g; Mg: 10 g; S: 15 g; Fe: 600 mg; Zn: 5.2 g; Cu: 1.800 g; Co: 0.2 g; Mn: 0.1 g; I: 0.1 g; Se: 0.03 g; F: 0.74 g; **Composition (em 1000g): Ca: 220 g; P: 160 g; Mg: 10 g; S: 15 g ; Fe: 2.61 g; Zn: 5.47 g; Cu: $2.1 \mathrm{~g}$; Mn: $0.99 \mathrm{~g}$; Co: $0.2 \mathrm{~g}$; I: $0.12 \mathrm{~g}$; Se: $0.045 \mathrm{~g} ; \mathrm{F}: 1.45 \mathrm{~g}$.

Source: Elaboration of the authors.

The crude glycerin used to elaborate the diets was the commercial product called GENPA (Glicerol Energético Nutricional para Alimentação Animal), that had $899.2 \mathrm{~g}$ dry matter $/ \mathrm{kg}$. The product composition per kilo of dry matter was $11.9 \mathrm{~g}$ ether extract, $78.6 \mathrm{~g}$ mineral matter, $803.5 \mathrm{~g}$ glycerin, $<0.1 \mathrm{~g}$ methanol and $74.7 \mathrm{~g}$ chlorides and was contaminants free and fully registered in the Ministério da Agricultura, Pecuária e Abastecimento (MAPA) from Brazil by the GRANOL SA company, located in the municipality of Anápolis-GO. This ingredient was incorporated in the diet concentrate fraction just before supplying each meal ( 9 a.m. and 4 p.m.). For this, due to the glycerin was in the crude state, the quantity included in the diet was determined by dividing the level ( $\mathrm{g} / \mathrm{kg}$ dry matter) supplied by crude glycerin density $\left(\mathrm{g} / \mathrm{cm}^{3}\right)$ measured in a $1000 \mathrm{~mm}$ test tube.

Foodstuff and leftovers samples were collected weekly, identified, placed in plastic bags and frozen at $-20^{\circ} \mathrm{C}$. Later, the samples were thawed and organized into composite samples per animal and per period. These samples were pre-dried in a ventilated oven at $55^{\circ} \mathrm{C}$ for 72 hours and processed in a grinder $(1 \mathrm{~mm})$ to determine the chemical composition (Table 2).

The contents of dry matter, crude protein and ether extract were determined according to the AOAC (1990). The neutral detergent insoluble nitrogen and acid detergent insoluble nitrogen were determined according to Licitra, Hernandez and Van Soest (1996) and the insoluble protein content 
was determined by multiplying the insoluble nitrogen content in the respective detergents by 6.25. The contents of neutral detergent fiber, acid detergent fiber and lignin were determined using the procedures by Van Soest (1973) and Van Soest, Roberttson and Lewis (1991). The total digestible nutrient content was estimated following the equations by Weiss (1993).

Table 2. Chemical composition of experimental diets.

\begin{tabular}{llllll}
\hline \multirow{2}{*}{$\begin{array}{l}\text { Food fraction } \\
(\mathrm{g} / \text { kg dry matter })\end{array}$} & Elephant grass silage & \multicolumn{4}{l}{$\begin{array}{l}\text { Crude glycerin in the diet } \\
(\mathrm{g} / \mathrm{kg} \text { dry matter })\end{array}$} \\
\cline { 3 - 5 } & & 0 & 60 & 120 & 240 \\
\hline Dry matter & 252.6 & 738.9 & 724.2 & 730.7 & 732.9 \\
Crude protein & 62.9 & 141.0 & 140.2 & 140.3 & 141.3 \\
Neutral detergente fiber & 749.0 & 231.9 & 225.3 & 216.9 & 201.1 \\
Acid detergente fiber & 501.6 & 134.1 & 131.5 & 130.9 & 124.4 \\
Lignin $_{\text {Neutral detergente insoluble protein }}{ }^{1}$ & 62.0 & 14.9 & 15.1 & 15.0 & 15.3 \\
Acid detergente insoluble protein $^{1}$ & 284.7 & 141.6 & 134.1 & 128.8 & 103.8 \\
Ether extract $^{\text {Total digestible nutrients }}$ & 158.4 & 108.7 & 91.5 & 95.0 & 82.4 \\
\hline
\end{tabular}

${ }^{1} \mathrm{~g}$ protein $/ \mathrm{kg}$ crude protein.

Source: Elaboration of the authors.

At the end of the experiment the animals were weighed and slaughtered without prior fasting in a commercial slaughterhouse with Federal Inspection Service. The fat trimmings were collected and weighed on the slaughterline. At the end of the slaughter line the carcass was weighed and the hot carcass weight was obtained. The whole carcass weight was obtained from the sum of the hot carcass with the respective fat trimming weights. The whole hot carcass yield was determined considering the whole carcass weight, and the hot carcass yield was determined considering the carcass weight after trimming the fat. After chilling for 24 hours at $0-2^{\circ} \mathrm{C}$, the carcasses were weighed and assessed for conformation, based on muscular expression, physiological maturity based on the degree of ossification of the spine processes of the thoracic vertebra and by the degree of fusion of the sacral vertebra according to Müller (1987).

The following metric measurements were taken in the right half carcass: carcass length, corresponding to the mean of the anterior edge of the pubic bone to the mid anterior edge of the first rib; leg thickness, measured with a compass placed between the side and mid surface of the upper portion of the leg; leg length, from the tibia-tarsian joint to the anterior edge of the pubis; arm length, from the carpal radial joint to the olecranon tip; arm perimeter, involving the mid-part of the radial cubital joint and the muscles that come with the region. A transversal cut was made in the Longissimus dorsi and muscle between the 12th and 13th ribs where subjective assessments were made on the degree of intra-muscular fat (marbling), meat coloring and texture (MÜLLER, 1987), and a pachymeter was used to measure the backfat thickness (EGS) that covers the muscle, using the mean of two readings. The outline of the Longissimus dorsi muscle was drawn on parchment paper to determine its area using the AUTOCAD $^{\circledR}$ software.

The methodology of Hankins and Howe (1946), adapted by Müller (1973), was used to determine the carcass muscle, fat and bone percentages. The portion of the Longissimus dorsi muscle extracted 
was identified, packed and immediately frozen at $-18^{\circ} \mathrm{C}$ to later examine losses through thawing and cooking, total losses and meat tenderness. Later, a $2.5 \mathrm{~cm}$ thick slice was removed from the Longissimus dorsi muscle and weighed. After thawing at chilling temperature $\left(4-10^{\circ} \mathrm{C}\right)$ for 24 hours, the slice was weighed again to obtain the thawing loss. After cooking to the internal temperature of $70^{\circ} \mathrm{C}$, the slice was weighed again to obtain the loss from cooking. Then a cylindrical sample was removed longitudinally to the muscle fibers to determine the shear force (tenderness) by the Warner Bratzler Shear apparatus, considering the mean of the readings after discounting the maximum and minimum values.
The data were submitted to variance analysis and polynomial regression using the SISVAR ${ }^{\circledR}$ software and the means were compared by the Tukey test, considering $\alpha=0.05$. The means of the variables with non-normal distribution were compared by the Kruskal and Wallis test (1952), followed by the Conover procedure (1980).

\section{Results and Discussion}

There was no interaction $(\mathrm{P}>0.05)$ between crude glycerin level in the diet and animal category for most of the carcass and meat characteristics, except for whole hot carcass weight and backfat thickness (Table 3).

Table 3. Variables related to carcass and meat characteristics of cows and steer finished in a feedlot with crude glycerin levels in the diets.

\begin{tabular}{|c|c|c|c|c|c|c|c|c|}
\hline \multirow[t]{2}{*}{ Itens } & \multirow[t]{2}{*}{ Sex } & \multicolumn{4}{|c|}{$\begin{array}{l}\text { Crude glycerin in the diet } \\
\text { (g/kg dry matter) }\end{array}$} & \multirow[t]{2}{*}{ Mean } & \multicolumn{2}{|c|}{ Regression } \\
\hline & & 0 & 60 & 120 & 240 & & $\mathrm{~L}$ & Q \\
\hline \multirow{2}{*}{ WHCW } & $\mathrm{C}$ & $303.5 \pm 36^{\mathrm{a}}$ & $305.6 \pm 25^{\mathrm{a}}$ & $293.5 \pm 33^{\mathrm{a}}$ & $298.7 \pm 15^{\mathrm{a}}$ & $300.3 \pm 28$ & 0.80 & 0.85 \\
\hline & S & $242.5 \pm 25^{b}$ & $240.8 \pm 20^{\mathrm{b}}$ & $242.8 \pm 44^{\mathrm{a}}$ & $258.0 \pm 28^{a}$ & $246.0 \pm 31$ & 0.55 & 0.75 \\
\hline \multirow{2}{*}{$\mathrm{HCW}$} & C & $282.3 \pm 36$ & $284.0 \pm 25$ & $272.2 \pm 30$ & $279.0 \pm 18$ & $279.4 \pm 28^{\mathrm{a}}$ & 0.86 & 0.75 \\
\hline & S & $224.7 \pm 22$ & $228.0 \pm 19$ & $228.7 \pm 41$ & $244.8 \pm 26$ & $231.5 \pm 29^{b}$ & 0.46 & 0.82 \\
\hline \multirow{4}{*}{ CFT } & $\mathrm{C}$ & $21.2 \pm 2$ & $21.6 \pm 1$ & $21.3 \pm 3$ & $19.6 \pm 3$ & $20.9 \pm 2$ & 0.62 & 0.74 \\
\hline & S & $17.8 \pm 8$ & $12.7 \pm 1$ & $14.1 \pm 3$ & $13.1 \pm 4$ & $14.4 \pm 5$ & 0.32 & 0.41 \\
\hline & $\mathrm{C}$ & $52.3 \pm 3$ & $54.6 \pm 11$ & $54.7 \pm 8$ & $55.1 \pm 6$ & $54.2 \pm 7$ & 0.65 & 0.75 \\
\hline & $\mathrm{S}$ & $53.7 \pm 1$ & $52.2 \pm 1$ & $54.4 \pm 1$ & $54.9 \pm 1$ & $53.8 \pm 1$ & 0.72 & 0.90 \\
\hline \multirow{2}{*}{$\mathrm{HCY}$} & $\mathrm{C}$ & $48.6 \pm 3$ & $50.7 \pm 10$ & $50.7 \pm 8$ & $51.4 \pm 7$ & $50.4 \pm 7$ & 0.63 & 0.81 \\
\hline & $\mathrm{S}$ & $49.8 \pm 1$ & $49.5 \pm 1$ & $51.3 \pm 1$ & $52.1 \pm 1$ & $50.7 \pm 1$ & 0.59 & 0.98 \\
\hline
\end{tabular}

Means followed by different lowercase letters in the column differ $(\mathrm{P}>0.05)$ by the Tukey test; $\mathrm{L}$ and $\mathrm{Q}=$ probability for the linear and quadratic model, respectively; $\mathrm{C}=$ cows; $\mathrm{S}=$ steer; $\mathrm{WHCW}=$ whole hot carcass weight $(\mathrm{kg})$; $\mathrm{CFT}=$ carcass fat trimmings $(\mathrm{kg}) ; \mathrm{WHCY}=$ whole hot carcass yield $(\mathrm{kg} / 100 \mathrm{~kg}$ carcass); $\mathrm{HCW}=$ hot carcass weight $(\mathrm{kg}) ; \mathrm{HCY}=$ hot carcass yield $(\mathrm{kg} / 100 \mathrm{~kg}$ bodyweight).

Source: Elaboration of the authors.

The whole hot carcass weight was greater $(\mathrm{P}<0.05)$ for the cows than for the steer in the diets with 0 and $60 \mathrm{~g}$ crude glycerin/dry matter but no difference was observed between cows and steer for the other diets. After trimming of fat from carcass, that was not altered $(\mathrm{P}>0.05)$ by the factors studied, the hot carcass weight was similar among the crude glycerin levels studied, a fact associated to the similar body development that resulted from the nutrient supply of the diets and variation in the carcass backfat thickness.

The hot carcass weight was greater $(\mathrm{P}<0.05)$ in the cows compared to the steer (Table 3 ), that was 
associated to greater body development of the cows than steer (559.4 vs $457.2 \mathrm{~kg}$ body weight) a fact that resulted partly from higher age and shown by the significant correlation $(r=0.74)$ between the slaughter and hot carcass weight. The results for carcass weights are in agreement with those obtained by Restle et al. (2001) and Vaz et al. (2002), who observed that cows presented heavier carcasses than steer.

Inclusion of crude glycerin in the diet did not alter $(\mathrm{P}>0.05)$ the whole carcass yield and the hot carcass yield (Table 3), a different result from that obtained by Carvalho et al. (2009) who assessed crude glycerin in the diets of Red Norte bulls and observed increased carcass yield that was justified by the increase in energy intake. However, Parsons, Shelor and Drouillard (2009) reported that increased crude glycerin level in steer diets decreased carcass yield, that was related to the decrease in the body weight gain. On the other hand, the results in the present study were according Gomes et al. (2011), who assessed replacing corn with 100 or 300 $\mathrm{g}$ crude glycerin/diet in dry matter and did not observed variation in the commercial carcass yield of feedlot Santa Inês lambs. This was a reflection of similar tissue deposits in the carcass because of the similar body weight gain, which also occurred in the present study (LEÃO, 2011).

The whole and hot carcass yields were similar $(\mathrm{P}>0.05$ ) among cows and steer (Table 3). However, the effect on carcass weight was striking of fat trimming on the slaughter line, $-20.9 \mathrm{~kg}$ in the cows and $-14.4 \mathrm{~kg}$ in the steer, resulting in the loss of 3.8 and 3.1 percentage, respectively, of hot carcass yield compared to the whole carcass yield. Although the difference was slightly greater in the cows, that can be considered less harmed by fat trimming because the backfat thickness was 2.6 times greater than in steer.

The similarity in the carcass yield between males and females observed in the present study does not usually occur between these categories in the beef cattle breeds, when slaughtered at the same degree of finishing, resulting in highest carcass yield in the males (VAZ et al., 2002, 2010). As commented by Ferreira et al. (2009), for cows to achieve similar yield to the steer greater fat deposition is necessary in the cow than in the steer carcass. The effect of fat disposition on cow carcass yield was evident in the study by Kuss et al. (2005), who observed that with increased backfat thickness from 4.72 to $7.54 \mathrm{~mm}$, the hot carcass yield increased significantly from 51.9 to $54.93 \mathrm{~kg}$ hot carcass $/ 100 \mathrm{~kg}$ live weight. In the present study, backfat thickness cow was 3.78 $\mathrm{mm}$ vs. $5.18 \mathrm{~mm}$ for the steer, that explained the similarity in the yield observed between the two categories.

The backfat thickness was not altered $(\mathrm{P}>0.05)$ by the crude glycerin level (Table 4) that reached the slaughterhouse minimum requirement of 3 $\mathrm{mm}$ in all the treatments (RESTLE; BRONDANI; BERNARDES, 1999; COSTA et. al., 2002). This fact is important because it gives the carcass a better visual appearance (MÜLLER, 1987), reduces liquid loss from hot carcass during chilling and the carcass temperature falls more slowly so that there is less muscle fiber shortening due to the cold (LAWRIE, 2005).

In spite of the benefits to the carcass and meat, the excess cover fat can represent losses to the producer, both from fat trimmings on the slaughter line for which he is not paid, and for the greater quantity of food consumed by the animals for its deposition, that decreases the food efficiency (ARBOITTE et al., 2004; COSTA et al., 2002).

The greater fat disposition in the cows was due to their more advanced development stage, because as the animal ages the intensity of fat deep position increases (BERG; BUTTERFIELD, 1976). These assumptions were shown in the present study by significant correlation $(\mathrm{r}=0.65)$ of the backfat thickness with slaughter weight and by the inverse ratio between muscle and fat quantity on the carcass $(\mathrm{r}=0.90)$. 
Table 4. Variables related to qualitative carcass and meat characteristics of cows and steer finished in a feedlot with crude glycerin levels in the diets.

\begin{tabular}{|c|c|c|c|c|c|c|c|c|}
\hline \multirow[t]{2}{*}{ Itens } & \multirow[t]{2}{*}{ Sex } & \multicolumn{4}{|c|}{$\begin{array}{l}\text { Crude glycerin in the diet } \\
\text { (g/kg dry matter) }\end{array}$} & \multirow[t]{2}{*}{ Mean } & \multicolumn{2}{|c|}{ Regression } \\
\hline & & 0 & 60 & 120 & 240 & & $\mathrm{~L}$ & Q \\
\hline \multirow{2}{*}{$\mathrm{BT}^{1}$} & C & $16.5 \pm 4$ & $10.0 \pm 3$ & $17.7 \pm 4$ & $10.9 \pm 5$ & $13.8 \pm 5^{\mathrm{a}}$ & 0.28 & 0.69 \\
\hline & S & $3.7 \pm 1$ & $6.3 \pm 3$ & $4.5 \pm 3$ & $6.3 \pm 2$ & $5.2 \pm 3^{\mathrm{b}}$ & 0.53 & 0.90 \\
\hline \multirow{2}{*}{$\mathrm{CON}^{2}$} & $\mathrm{C}$ & $10.3 \pm 1$ & $10.3 \pm 2$ & $9.3 \pm 1$ & $10.7 \pm 1$ & $10.2 \pm 1$ & 0.64 & 0.42 \\
\hline & $\mathrm{S}$ & $10.3 \pm 1$ & $10.0 \pm 1$ & $10.3 \pm 2$ & $11.0 \pm 1$ & $10.4 \pm 1$ & 0.11 & 0.30 \\
\hline \multirow{2}{*}{$\mathrm{PM}^{2}$} & $\mathrm{C}$ & $5.3 \pm 1$ & $5.3 \pm 2$ & $5.3 \pm 1$ & $6.0 \pm 2$ & $5.5 \pm 2^{\mathrm{b}}$ & 0.56 & 0.76 \\
\hline & $\mathrm{S}$ & $10.3 \pm 1$ & $11.0 \pm 1$ & $11.7 \pm 2$ & $10.7 \pm 1$ & $10.9 \pm 1^{\mathrm{a}}$ & 0.82 & 0.29 \\
\hline \multirow{2}{*}{$\mathrm{LDA}^{1}$} & $\mathrm{C}$ & $76.5 \pm 7^{\mathrm{a}}$ & $78.0 \pm 13^{\mathrm{a}}$ & $64.9 \pm 5^{\mathrm{a}}$ & $76.3 \pm 7^{\mathrm{a}}$ & $73.9 \pm 9$ & 0.77 & 0.19 \\
\hline & $\mathrm{S}$ & $65.3 \pm 7^{\mathrm{a}}$ & $60.2 \pm 7^{b}$ & $69.8 \pm 8^{\mathrm{a}}$ & $72.2 \pm 12^{\mathrm{a}}$ & $66.9 \pm 9$ & 0.19 & 0.77 \\
\hline \multirow{2}{*}{$\mathrm{LDA} 100^{1}$} & $\mathrm{C}$ & $27.3 \pm 2^{a}$ & $27.9 \pm 7^{\mathrm{a}}$ & $24.0 \pm 1^{\mathrm{b}}$ & $27.5 \pm 4^{\mathrm{a}}$ & $26.7 \pm 4$ & 0.91 & 0.36 \\
\hline & $\mathrm{S}$ & $29.1 \pm 2^{\mathrm{a}}$ & $26.4 \pm 2^{\mathrm{a}}$ & $31.1 \pm 4^{\mathrm{a}}$ & $29.5 \pm 4^{\mathrm{a}}$ & $29.0 \pm 3$ & 0.60 & 0.91 \\
\hline
\end{tabular}

${ }_{1,2}$ Means followed by different lowercase letters in the column differ $(\mathrm{P}<0.05)$ by the Tukey and Kruskall-Wallis tests, respectively; $\mathrm{L}$ and $\mathrm{Q}=$ probability for linear and quadratic model; $\mathrm{C}=\operatorname{cows} ; \mathrm{S}=$ steer; $\mathrm{BT}=$ backfat thickness $(\mathrm{mm}) ; \mathrm{CON}=$ conformation $(10$ 12 points = good); $\mathrm{PM}=$ physiological maturity (4-6: from 5.5 to 8 years old; 10-12: from 2.5 to 4 years old); LDA = Longissimus dorsi area $\left(\mathrm{cm}^{2}\right)$; LDA100 $=$ Longissimus dorsi area $\left(\mathrm{cm}^{2} / 100 \mathrm{~kg}\right.$ hot carcass $)$.

Source: Elaboration of the authors.

The crude glycerin level in the diets did not alter $(\mathrm{P}>0.05)$ the carcass conformation (Table 4$)$, showing that this by-product up to $240 \mathrm{~g} / \mathrm{kg}$ dry matter diet did not alter the muscular deposition, a fact related to the similar animal performance, with a mean of $1.430 \mathrm{~g} /$ day. However, according to Parsons, Shelor and Drouillard (2009), adding over $80 \mathrm{~g} / \mathrm{kg}$ dry matter, the crude glycerin decreases weight gain in heifers, and may depress muscle deposition and carcass conformation. However, Gunn et al. (2010) assessed doses of the same byproduct in sheep diet $(0,150,300$ and $450 \mathrm{~g} /$ $\mathrm{kg}$ dry matter) and suggested that only quantities greater than $300 \mathrm{~g}$ crude glycerin/diet dry matter can cause harmful effects to the carcass characteristics. Corroborating, Gunn et al. (2010) stated that including up to $150 \mathrm{~g}$ crude glycerin $/ \mathrm{kg}$ dry matter diet increased animal performance and improved the sheep carcass characteristics.

The carcass conformation did not differ $(\mathrm{P}>0.05)$ between cows and steer, and the carcasses of both categories were classified as "typically good" (Table 4). These results were different from those observed by et al. (2002a) in Hereford breed animals where steer presented carcasses with superior conformation compared to the cows, both finished in a feedlot and with similar backfat thickness. The subjective assessment of the conformation is based on the muscular expression of the carcass, and the assessment does not consider the covering fat. However, intramuscular and intermuscular fat deposition can influence the leg volume that is the assessment base, and can favor conformation, a fact shown by correlation $(\mathrm{P}>0.05)$ of the leg thickness with backfat thickness $(\mathrm{r}=0.52)$ and total fat quantity in the carcass $(\mathrm{r}=0.59)$.

Thus it was assumed that the cows that presented, in the mean of the treatments, $13.8 \mathrm{~mm}$ backfat thickness vs $5.2 \mathrm{~mm}$ in the steer and also deposited a greater quantity of intra-muscular fat, corroborated by the greater degree of marbling (Table 7) and greater fat proportion in the carcass assessed by physical separation of $\mathrm{HH}$ section that includes subcutaneous and intermuscular fat. These indications were also reported by Ferreira et al. (2009) who observed similarity in the conformation of crossbred Charolês $\mathrm{x}$ Nelore animals, with superior backfat thickness for cows (6.21 vs 3.83 
$\mathrm{mm}$ ). For Pascoal et al. (2010) the conformation indicated the total yield of meat cuts of the carcass contrary to the carcass weight. According to these authors, steer carcasses with better conformation produce a higher total yield of meat cuts, a fact that in the present study was shown by the positive correlation $(\mathrm{P}>0.05)$ between conformation and muscle quantity on the carcass $(\mathrm{r}=0.63)$.

Pascoal et al. (2009) studied the same categories as in the present study, but in Bradford breed animals and stated that although the cows had worse conformations than steer, the total meat cut yield of the carcass was similar. These indications showed that is important to compare cow and steer carcass characteristics because of aspects related to the internal market, where cow carcasses are usually penalized with less remuneration to the producer while there is no categorical definition regarding the price of the meat offered to the consumer.

The carcass physiological maturity was not influenced $(\mathrm{P}>0.05)$ by the crude glycerin content of the diet (Table 4) but the cow carcasses presented more advanced maturity, with ossified cartilages of the spine processes, and the separation line could still be visualized between the spine processes of the thoracic vertebras and the ossified cartilage. In the steer, the carcass showed a lesser degree of maturity, and the cartilage of the spine processes had a certain degree of all ossification, and the separation of the sacral vertebra was less clear (MÜLLER, 1987). The higher physiological maturity in the cow carcasses compared to the steer carcasses was related to the higher age and body development, in agreement with the results obtained by Vaz et al. (2002) and Ferreira et al. (2009). These assumptions were also shown in the present study by the inverse correlation $(\mathrm{P}<0.05)$ between carcass physiological maturity $(\mathrm{r}=0.73)$ and slaughter weight.

The Longissimus dorsi area, expressed in $\mathrm{cm}^{2}$ was greater $(\mathrm{P}<0.05)$ in the cows fed diets with 60 g crude glycerin/diet dry matter compared to the steer on the same diet (Table 4). When expressed in function of carcass weight ( $\mathrm{cm}^{2} / 100 \mathrm{~kg}$ hot carcass), the Longissimus dorsi area was superior for steer fed diet with $120 \mathrm{~g}$ crude glycerin/kg diet dry matter, results that may indicate variations associated to the body size of the animals.

Mach, Bach and Devant (2009) did not report differences for Longissimus dorsi area in bulls slaughtered at $460 \mathrm{~kg}$ body weight and fed up to $121 \mathrm{~g}$ crude glycerin/kg dry matter diet. However, Parsons, Shelor and Drouillard (2009) reported linear reduction of this characteristic in crossbred steer carcasses using 20 and 160 crude glycerin/kg dry matter diet, resulting in decreased daily weight gain. It is emphasized that in the characteristics linked to muscular expression of the carcass, such as conformation, leg thickness and Longissimus dorsi area are important because they are directly associated with the edible portion of the carcass and because they determine higher yield of the secondary cuts (PASCOAL et al., 2009).

Carcass length was not altered $(\mathrm{P}>0.05)$ by the crude glycerin level in the diets (Table 5) that reflected the similar body development resulting from diets. However, this characteristic was inferior in the steer compared to the cows, demonstrating that the steer were still in the growing phase. Similar findings were reported by Ferreira et al. (2009) and Vaz et al. (2002).

The difference in carcass length between cows and steer was explained by the greater body development of the cows, that may have been associated to age but also to the organism adaptations to accommodate the fetus during pregnancy because in this category greater development has been observed of the plate commercial cut (VAZ et al., 2002) that according to Kuss et al. (2005) there is an increased carcass length due to the pressure between the ribs caused by fat deposit. 
Table 5. Variables related to metric characteristics of the carcasses of cows and steer finished in a feedlot with crude glycerin levels in the diet.

\begin{tabular}{|c|c|c|c|c|c|c|c|c|}
\hline \multirow[t]{2}{*}{ Itens } & \multirow[t]{2}{*}{ Sex } & \multicolumn{4}{|c|}{$\begin{array}{l}\text { Crude glycerin in the diet } \\
\text { (g/kg dry matter) }\end{array}$} & \multirow[t]{2}{*}{ Mean } & \multicolumn{2}{|c|}{ Regression } \\
\hline & & 0 & 60 & 120 & 240 & & $\mathrm{~L}$ & Q \\
\hline \multirow{2}{*}{$\mathrm{CL}$} & $\mathrm{C}$ & $148.8 \pm 6$ & $151.1 \pm 5$ & $147.7 \pm 6$ & $148.3 \pm 2$ & $148.9 \pm 5^{\mathrm{a}}$ & 0.76 & 0.93 \\
\hline & $S$ & $135.7 \pm 3$ & $135.7 \pm 2$ & $133.8 \pm 6$ & $132.6 \pm 4$ & $134.4 \pm 4^{b}$ & 0.45 & 0.99 \\
\hline \multirow{2}{*}{ AP } & $\mathrm{C}$ & $35.5 \pm 1$ & $36.0 \pm 2$ & $34.5 \pm 2$ & $34.8 \pm 2$ & $35.2 \pm 2$ & 0.53 & 0.85 \\
\hline & $\mathrm{S}$ & $34.7 \pm 1$ & $34.8 \pm 1$ & $33.3 \pm 3$ & $35.8 \pm 2$ & $34.7 \pm 2$ & 0.52 & 0.27 \\
\hline \multirow{2}{*}{$\mathrm{AL}$} & $\mathrm{C}$ & $40.3 \pm 1$ & $41.3 \pm 1$ & $40.0 \pm 2$ & $40.7 \pm 1$ & $40.6 \pm 1$ & 0.98 & 0.98 \\
\hline & $\mathrm{S}$ & $42.0 \pm 2$ & $42.8 \pm 1$ & $40.3 \pm 2$ & $40.0 \pm 2$ & $41.3 \pm 2$ & 0.59 & 1.00 \\
\hline \multirow{2}{*}{ LL } & $\mathrm{C}$ & $71.6 \pm 4$ & $71.3 \pm 2$ & $72.0 \pm 3$ & $70.0 \pm 2$ & $71.2 \pm 3$ & 0.52 & 0.68 \\
\hline & $\mathrm{S}$ & $73.4 \pm 2$ & $74.0 \pm 1$ & $74.5 \pm 4$ & $72.9 \pm 3$ & $73.7 \pm 2$ & 0.82 & 0.60 \\
\hline \multirow{2}{*}{ LT } & $\mathrm{C}$ & $25.1 \pm 1^{\mathrm{a}}$ & $24.8 \pm 2^{\mathrm{a}}$ & $25.2 \pm 1^{\mathrm{a}}$ & $24.6 \pm 1^{\mathrm{a}}$ & $24.9 \pm 1$ & 0.67 & 0.86 \\
\hline & $\mathrm{S}$ & $22.3 \pm 1^{b}$ & $23.3 \pm 1^{\mathrm{a}}$ & $23.8 \pm 1^{\mathrm{a}}$ & $24.3 \pm 1^{\mathrm{a}}$ & $23.4 \pm 1$ & 0.07 & 0.51 \\
\hline
\end{tabular}

Means followed by different lowercase letters in the column differ $(\mathrm{P}<0.05)$ by the Tukey test; $\mathrm{L}$ and $\mathrm{Q}=$ probability for linear and quadratic model, respectively; $\mathrm{C}=$ cows; $\mathrm{S}=$ steer; $\mathrm{AL}=$ arm length $(\mathrm{cm}) ; \mathrm{LL}=$ leg length $(\mathrm{cm}) ; \mathrm{CL}=\mathrm{carcass}$ length $(\mathrm{cm}) ; \mathrm{LT}=$ leg thickness $(\mathrm{cm}) ; \mathrm{AP}=$ arm perimeter $(\mathrm{cm})$.

Source: Elaboration of the authors.

The arm length and perimeter and leg length were not altered $(\mathrm{P}>0.05)$ by the crude glycerin level in the diets or by the animal category (Table 5). These results may have been associated to the tissue deposition profile in the carcass due to the bone deposition, that is one of the main tissues of the members and sustains the body, develops during the first stage of animal growth (BERG; BUTTERFIELD, 1976).
Cows fed diets without crude glycerin presented greater $(\mathrm{P}<0.05)$ leg thickness compared to steer fed the same diet (Table 5). However, this characteristic was not altered $(\mathrm{P}>0.05)$ by animal category or crude glycerin presence at different levels in the other diets. Cows fed diets without crude glycerin and with $120 \mathrm{~g}$ crude glycerin/kg dry matter diet presented lowest $(\mathrm{P}<0.05)$ muscle and bone quantity and highest fat quantity in the carcass compared to the steer fed the respective diets (Table 6).

Table 6. Variables related to tissue composition of the carcasses of cows and steer finished in a feedlot with crude glycerin levels in the diet.

\begin{tabular}{|c|c|c|c|c|c|c|c|c|}
\hline \multirow[t]{2}{*}{ Itens $^{1}$} & \multirow[t]{2}{*}{ Sex } & \multicolumn{4}{|c|}{$\begin{array}{l}\text { Crude glycerin in the diet } \\
\text { (g/kg dry matter) }\end{array}$} & \multirow[t]{2}{*}{ Mean } & \multicolumn{2}{|c|}{ Regression } \\
\hline & & 0 & 60 & 120 & 240 & & $\mathrm{~L}$ & Q \\
\hline \multirow{2}{*}{ Muscle } & $\mathrm{C}$ & $56.83 \pm 3^{b}$ & $58.7 \pm 3^{\mathrm{a}}$ & $53.4 \pm 1^{\mathrm{b}}$ & $58.1 \pm 3^{\mathrm{a}}$ & $56.8 \pm 2$ & 0.24 & 0.21 \\
\hline & $\mathrm{S}$ & $62.4 \pm 3^{\mathrm{a}}$ & $58.6 \pm 3^{a}$ & $62.2 \pm 2^{\mathrm{a}}$ & $61.4 \pm 2^{\mathrm{a}}$ & $61.2 \pm 3$ & 0.92 & 0.55 \\
\hline \multirow{2}{*}{ Bone } & $\mathrm{C}$ & $11.9 \pm 1^{\mathrm{b}}$ & $12.7 \pm 1^{\mathrm{b}}$ & $12.4 \pm 1^{\mathrm{a}}$ & $12.8 \pm 1^{a}$ & $12.5 \pm 1$ & 0.50 & 0.78 \\
\hline & $\mathrm{S}$ & $14.3 \pm 1^{\mathrm{a}}$ & $15.6 \pm 2^{\mathrm{a}}$ & $13.2 \pm 1^{\mathrm{a}}$ & $13.7 \pm 2^{\mathrm{a}}$ & $14.2 \pm 2$ & 0.20 & 0.98 \\
\hline \multirow{2}{*}{ Fat } & $\mathrm{C}$ & $33.3 \pm 3^{\mathrm{a}}$ & $30.2 \pm 4^{\mathrm{a}}$ & $36.1 \pm 1^{\mathrm{a}}$ & $30.8 \pm 3^{a}$ & $32.6 \pm 4$ & 0.65 & 0.36 \\
\hline & $\mathrm{S}$ & $24.3 \pm 3^{b}$ & $26.2 \pm 3^{\mathrm{a}}$ & $26.2 \pm 2^{b}$ & $26.3 \pm 3^{\mathrm{a}}$ & $25.7 \pm 3$ & 0.55 & 0.61 \\
\hline
\end{tabular}

Means followed by different lowercase letters in the column differ $(\mathrm{P}<0.05)$ by the Tukey test; $\mathrm{L}$ and $\mathrm{Q}=$ probability for linear and quadratic model, respectively, $\mathrm{C}=$ cows; $\mathrm{S}=$ steer; ${ }^{1} \mathrm{~kg} / 100 \mathrm{~kg}$ hot carcass.

Source: Elaboration of the authors. 
Carvalho et al. (2009) assessed crude glycerin inclusion in diets for Red Norte bulls and reported that this byproduct at up to $180 \mathrm{~g} / \mathrm{kg}$ dry matter diet did not damage the animal performance, carcass and meat characteristics or the finishing, and improved the carcass yield, a fact attributed to the greater energy intake. It is emphasized that the intensity of tissue deposition is influenced by sex and age (NRC, 1996) that determine differences in the carcass tissue composition of animals of different categories. It is further emphasized that bone and muscular growth is prioritized initially in tissue development and it decreases gradually when the animal reaches physiological maturity, due to the higher deposition of adipose tissue (BERG; BUTTERFIELD, 1976). These aspects were shown in the present study by the correlation $(\mathrm{P}<0.05)$ of physical maturity with muscle quantity $(\mathrm{r}=0.67)$, fat $(\mathrm{r}=0.75)$ and bone $(\mathrm{r}=0.52)$ in the carcass, considering that the physiological maturity score is higher when the age is less.

Meat tenderness, assessed by the Warner Bratzler Shear apparatus was not altered $(\mathrm{P}>0.05)$ by the crude glycerin level in the diet (Table 7), in agreement with results by Mach Bach and Devant (2009) and Gomes et al. (2011). Meat tenderness was similar $(\mathrm{P}>0.05)$ between cows and steer, in disagreement with the inferences by Müller (1987), who stated that tenderness decreases with the increasing age of the animals. Thus less tenderness in the meat was expected due the higher age of the cows. This fact was observed by Vaz et al. (2002) who classified steer as medium and cows meat tenderness as slightly below the average.

It was emphasized that meat tenderness is associated to the fat deposition in the carcass (MÜLLER, 1987; KUSS et al., 2005), weight gain speed and soluble collagen deposition (CROUSE; CALKINS; SEIDEMAN, 1986). In this sense it was observed in the present study that cow meat presented a highest $(\mathrm{P}<0.05)$ quantity of marbling that favors tenderness (KAUFFMAN; MARSCH, 1994). Another relevant aspect was the high backfat thickness in the cow carcasses compared to the steer (13.8 vs $5.2 \mathrm{~mm})$ that should have resulted in a slower fall in the internal muscle temperature and thus reduced shortening due to cold and favoring meat tenderness. These aspects resulted in similar meat tenderness between the categories, in agreement with results by Cattelam et al. (2009). It can be assumed from these results that cow meat tenderness can be similar steer meat, at least when there is high fat deposit in the cow carcass.

The level of crude glycerin inclusion did not alter $(\mathrm{P}>0.05)$ the meat coloring (Table 7$)$ results in according with those by Mach Bach and Devant (2009) and Gomes et al. (2011). However, it was observed that cows presented darker color meat $(\mathrm{P}<0.05)$ as compared to the steer. The difference in cow and steer meat color may be associated to the difference in age among the animals (approximately 30 months). These assumptions are in according with Müller (1987) who stated that meat color was associated to the animal age. This statement is supported by observation of Boggs and Merkel (1981) that meat color tends to become darker due to the increase in the quantity of myoglobin as the animals age.

The crude glycerin levels did not alter $(\mathrm{P}>0.05)$ the meat marbling (Table 7), a reflection of the similar body weight gain during the experimental period (LEÃO, 2011). Gunn et al. (2010) theorized that it would be expected that the intramuscular fat increased in virtue of the increased glucose resulting from the glycerin metabolism. Although they did not assess marbling, these authors observed that lamb carcass coverfat decreased linearly with increased crude glycerin level in the diet. Corroborating Parsons, Shelor and Drouillard (2009) observed that increased crude glycerin in the diet decreased the degree of marbling in heifer carcasses. It is emphasized that decrease in the carcass fat observed in the studies mentioned may be related to the decrease in body weight gain, a fact not shown in the present study. 
Table 7. Variables related to the quantitative characteristics of meat from cows and steer finished in feedlot with crude glycerin levels in the diet.

\begin{tabular}{|c|c|c|c|c|c|c|c|c|}
\hline \multirow[t]{2}{*}{ Itens } & \multirow[t]{2}{*}{ Sex } & \multicolumn{4}{|c|}{$\begin{array}{l}\text { Crude glycerin in the diet } \\
(\mathrm{g} / \mathrm{kg} \text { dry matter })\end{array}$} & \multirow[t]{2}{*}{ Mean } & \multicolumn{2}{|c|}{ Regression } \\
\hline & & 0 & 60 & 120 & 240 & & $\mathrm{~L}$ & Q \\
\hline \multirow{2}{*}{ Tenderness $^{1}$} & $\mathrm{C}$ & $8.1 \pm 1.5$ & $7.9 \pm 2.4$ & $6.6 \pm 1.0$ & $7.4 \pm 0.7$ & $7.5 \pm 1.52$ & 0.55 & 0.45 \\
\hline & $S$ & $8.5 \pm 1.6$ & $7.1 \pm 1.2$ & $7.02 \pm 2.4$ & $8.3 \pm 0.7$ & $7.7 \pm 1.62$ & 0.95 & 0.23 \\
\hline \multirow{2}{*}{ Color $^{2}$} & C & $2.8 \pm 0.3$ & $2.4 \pm 0.5$ & $2.9 \pm 0.1$ & $2.5 \pm 0.4$ & $2.7 \pm 0.4^{\mathrm{b}}$ & 0.74 & 0.86 \\
\hline & S & $3.3 \pm 0.4$ & $2.7 \pm 0.8$ & $3.3 \pm 0.9$ & $3.4 \pm 0.5$ & $3.2 \pm 0.7^{\mathrm{a}}$ & 0.46 & 0.49 \\
\hline \multirow{2}{*}{ Texture $^{2}$} & C & $2.9 \pm 0.3$ & $3.1 \pm 0.3$ & $2.8 \pm 0.9$ & $3.1 \pm 0.3$ & $2.9 \pm 0.5$ & 0.67 & 0.85 \\
\hline & S & $4.1 \pm 0.1$ & $2.5 \pm 0.6$ & $3.3 \pm 0.5$ & $2.9 \pm 0.5$ & $3.2 \pm 0.8$ & 0.15 & 0.13 \\
\hline \multirow{2}{*}{ Marbling ${ }^{2}$} & C & $13.7 \pm 0.5$ & $8.0 \pm 1.7$ & $9.0 \pm 2.7$ & $10.0 \pm 4.5$ & $10.2 \pm 3.3^{\mathrm{a}}$ & 0.38 & 0.10 \\
\hline & $\mathrm{S}$ & $5.7 \pm 3.9$ & $7.3 \pm 2.7$ & $5.3 \pm 1.1$ & $8.7 \pm 3.4$ & $6.7 \pm 3.3^{\mathrm{b}}$ & 0.36 & 0.65 \\
\hline
\end{tabular}

${ }^{1,2}$ Means followed by different lowercase letters in the column differ $(\mathrm{P}<0.05)$ by the Tukey and Kruskall-Wallis tests, respectively; $\mathrm{L}$ and $\mathrm{Q}=$ probability for the linear and quadratic model, respectively; $\mathrm{C}=$ cows; $\mathrm{S}=$ steer; tenderness $=\mathrm{kgf} / \mathrm{cm}^{3} ; \mathrm{color}: 2=\mathrm{dark}$ red; $3=$ slightly dark red; $4=$ red; Texture: $2=$ coarse; $3=$ slightly coarse; $4=$ fine; marbling: 4 to $6=$ slight; 7 to $9=$ small; 10 to 12 = medium; 13 to $15=$ moderate.

Source: Elaboration of the authors.

Regarding the animal categories studied, it was observed that the cows presented higher $(\mathrm{P}<0.05)$ quantity of intramuscular fat (marbling) than steer (Table 7) which may be associated to the higher finishing and quantity of fat deposited in the carcass because intramuscular fat is the last to be deposited (PETHICK et al., 2004) and is correlated with age, slaughter weight and carcass fat content (KAUFFMAN; MARSH, 1994; KUSS et al., 2005; MENEZES et. al., 2005). In the present study, marbling correlated significantly with carcass fat quantity $(r=0.30)$ and slaughter weight $(r=0.40)$, that corroborated with that exposed previously. The differences among animal categories for intramuscular fat quantity were also reported by Restle et al. (2001) and Vaz et al. (2002).
An important aspect of the higher degree of marbling in cow meat was that it was correlated with the meat palatability that can determine loyalty of certain consumer markets. Thus studies can be quoted that observed improvement in palatability with increase in the degree of marbling in the meat (PEROBELLI et al., 1994; RESTLE et al., 1996).

Liquid losses on thawing occurred regardless studied factors (Table 8). Cows fed diets including $60 \mathrm{~g}$ crude glycerin/kg dry matter diet presented higher liquid loss at thawing than steer, but no differences were observed for this characteristic in the other diets. These results disagreed with those by Gomes et al. (2011), who observed that increased crude glycerin in lamb diet did not alter loss at thawing, a fact associated with the similar carcass finishing. 
Table 8. Liquid loss during thawing and cooking of meat from cows and steer finished in feedlot with crude glycerin levels in the diet.

\begin{tabular}{|c|c|c|c|c|c|c|c|c|}
\hline \multirow[t]{2}{*}{ Itens } & \multirow[t]{2}{*}{ Sex } & \multicolumn{4}{|c|}{$\begin{array}{l}\text { Crude glycerin in the diet } \\
\text { (g/kg dry matter) }\end{array}$} & \multirow[t]{2}{*}{ Mean } & \multicolumn{2}{|c|}{ Regression } \\
\hline & & 0 & 60 & 120 & 240 & & $\mathrm{~L}$ & $\mathrm{Q}$ \\
\hline \multirow{2}{*}{ LT } & $\mathrm{C}$ & $15.2 \pm 1^{\mathrm{a}}$ & $15.2 \pm 1^{\mathrm{a}}$ & $16.5 \pm 3^{\mathrm{a}}$ & $15.8 \pm 2^{\mathrm{a}}$ & $15.7 \pm 2$ & 0.72 & 0.73 \\
\hline & $\mathrm{S}$ & $15.3 \pm 1 \mathrm{a}$ & $10.0 \pm 2^{b}$ & $13.2 \pm 3^{a}$ & $11.7 \pm 5^{\mathrm{a}}$ & $12.5 \pm 3$ & 0.35 & 0.35 \\
\hline \multirow{2}{*}{ LC } & $\mathrm{C}$ & $25.1 \pm 1^{\mathrm{a}}$ & $26.7 \pm 2^{\mathrm{a}}$ & $25.0 \pm 1^{\mathrm{a}}$ & $23.9 \pm 1^{\mathrm{b}}$ & $25.2 \pm 1$ & 0.26 & 0.32 \\
\hline & $\mathrm{S}$ & $26.3 \pm 2^{\mathrm{a}}$ & $25.9 \pm 3^{\mathrm{a}}$ & $24.4 \pm 3^{\mathrm{a}}$ & $27.8 \pm 1^{\mathrm{a}}$ & $26.1 \pm 2$ & 0.42 & 0.14 \\
\hline \multirow{2}{*}{ Total } & $\mathrm{C}$ & $34.9 \pm 2$ & $36.4 \pm 2$ & $35.6 \pm 2$ & $34.3 \pm 1$ & $35.3 \pm 2$ & 0.56 & 0.42 \\
\hline & $\mathrm{S}$ & $36.1 \pm 2$ & $32.6 \pm 4$ & $33.2 \pm 2$ & $35.3 \pm 2$ & $34.3 \pm 2$ & 0.99 & 0.07 \\
\hline
\end{tabular}

Means followed by different lowercase letters $\operatorname{differ}(\mathrm{P}<0.05)$ by the Tukey test; $\mathrm{L}$ and $\mathrm{Q}=$ probability for polynomial regression and quadratic equation, respectively; $\mathrm{C}=$ cows; $\mathrm{S}=$ steer; $\mathrm{LT}=$ losses at thawing $(\%) ; \mathrm{LC}=$ losses from cooking $(\%)$; Total = total losses (\%).

Source: Elaboration of the authors.

Liquid loss from cooking was higher $(\mathrm{P}<0.05)$ in meat from steer fed diet with $240 \mathrm{~g}$ crude glycerin/ $\mathrm{kg}$ dry matter diet compared to the cows but there was no difference for this characteristic between cows and steer for the other diets (Table 8), different from the results obtained by Gomes et al. (2011). However, total liquid loss was not altered $(\mathrm{P}>0.05)$ by introducing crude glycerin in the diet or by the animal categories studied. It is emphasized that there were no expected differences between categories for liquid loss from thawing and cooking in the diets with crude glycerin, although the total loss was not influenced by the factors studied, because these characteristics are related to fat deposition in the carcass. Other factors may have been related to the differences found, such as carcass chilling and pre-slaughter stress (KUSS et al., 2010; VAZ et al., 2010).

\section{Conclusion}

Crude glycerin can be added to the diet of crossbred cows and steer of dairy breeds in quantities up to $240 \mathrm{~g} / \mathrm{kg}$ dry matter without altering the yield indices and carcass and meat quality. Dairy cows discard present good meat and carcass characteristics compared to the steer and do not justify discrimination in the purchase price paid by the slaughterhouses.

\section{References}

ARBOITTE, M. Z.; RESTLE, J.; ALVES FILHO, D. C.; BRONDANI, I. L.; SILVA, J. H. S.; NORNBERG, J. L.; KUSS, F. Características da carcaça de novilhos 5/8 Nelore 3/8 Charolês abatidos em diferentes estádios de desenvolvimento. Revista Brasileira de Zootecnia, Viçosa, MG, v. 33, n. 4, p. 969-977, 2004.

ASSOCIATION OF OFFICIAL ANALYTICAL CHEMISTS - AOAC. Official methods of analysis. $15^{\text {th }}$ ed. Washington, D.C., 1990. 1141p.

BERG, R. T.; BUTTERFIELD, R. M. New concepts of cattle growth. Sydney: Sydney University Press, 1976. $240 \mathrm{p}$.

BOGGS, D. L.; MERKEL, R. A. Live animal: carcass evaluation and selection manual. Iowa: Michigan State University, 1981. 199 p.

CARVALHO, J. R. R.; LADEIRA, M. M.; CHIZZOTTI, M. L.; GONÇALVES, T. M.; OLIVEIRA, D. M.; NOGUEIRA NETO, A.; SILVA, P. T. Performance and carcass traits of bulls fed different levels of crude glycerin. Journal of Animal Science, Champaign, v. 84, p. 359, 2009.

CATTELAM, J.; MENEZES, L .F. G.; FERREIRA, J. J.; RESTLE, J.; BRONDANI, I. L.; ARBOITTE, M. Z.; PAULA, P. C. Composição física da carcaça e qualidade da carne de novilhos e vacas de descarte de diferentes grupos genéticos submetidos a diferentes freqüências de alimentação. Ciência Animal Brasileira, Goiânia, v. 10, n. 3, p. 764-775, 2009.

CONOVER, W. J. Practical nonparametric statistics. 2. ed. New York: Wiley, 1980. 
COSTA, E. C.; RESTLE, J.; PASCOAL, L. L.; VAZ, F. N.; ALVES FILHO, D. C.; ARBOITTE, M. Z. Características da carcaça de novilhos Red Angus superprecoces abatidos com diferentes pesos. Revista Brasileira de Zootecnia, Viçosa, MG, v. 31, n. 1, p. 119128, 2002.

CROUSE, J. D.; CALKINS, C. R.; SEIDEMAN, S. C. The effects of rate of change in body weight on tissue development and meat quality of youthful bulls. Journal of Animal Science, Champaign, v. 63, n. 6, p. 1824-1829, 1986.

DONKIN, S. S. Glycerol from biodiesel production: the new corn for dairy cattle. Revista Brasileira de Zootecnia, Viçosa, MG, v. 37, p. 280-286, 2008. Especial.

FERREIRA, J.J.;RESTLE, J.;BRONDANI, I.L.;ALVES FILHO, D. C.; CALLEGARO, A. M. Características de carcaça de vacas de descarte e novilhos mestiços Charolês $\times$ Nelore em confinamento sob diferentes frequências de alimentação. Revista Brasileira de Zootecnia, Viçosa, MG, v. 38, n. 10, p. 1974-1982, 2009.

GOMES, M. A. B.; MORAES, G. V.; MATAVELI, M.; MACEDO, F. A. F.; CARNEIRO, T. T.; ROSSI, R. M. Performance and carcass characteristics of lambs fed on diets supplemented with glycerin from biodiesel production. Revista Brasileira de Zootecnia, Viçosa, MG, v. 40, n. 10, p. 2211-2219, 2011.

GUNN, P. J.; SCHULTZ, A. F.; VAN ENOM, M. L.; NEARY, M. K.; LEMENAGER, C. P.; RUSK, C. P.; LAKE, L. Effects of elevated crude glycerin concentrations on feedlot performance, carcass characteristics, and serum metabolite and hormone concentrations in finishing ewe and wether lambs. The Professional Animal Scientist, Champaign, v. 26, n. 3, p. 298-306, 2010.

HANKINS, O. G.; HOWE, P. E. Estimation of the composition of beef carcasses and cuts. Washington: U.S. Department of Agriculture, 1946. v. 21, 926 p.

KAUFFMAN, R. G.; MARSH, B. B. Características de calidad del músculo como alimento. In: PRICE, J. F.; SCHWEIGERT, B. S. Ciencia de la carne y de los productos carnicos. 2. ed. Zaragoza: Acribia, 1994. cap. 9, p. 317-336.

KRUSKAL, W. H.; WALLIS, W. A. Use of ranks and on criterion variance analysis. Journal American Statistic Association, v. 47, n. 260, p. 583-621, 1952.

KUSS, F.; LÓPEZ, J.; RESTLE, J.; BARCELLOS, J. O.; MOLETTA, J.; LEITE, M. C. Qualidade da carne de novilhos terminados em confinamento e abatidos aos 16 ou 26 meses de idade. Revista Brasileira de Zootecnia, Viçosa, MG, v. 39, n. 4, p. 924-931, 2010.
KUSS, F.; RESTLE, J.; BRONDANI, I.L. PASCOAL, L. L. ; MENEZES, L. F. G.; PAZDIORA, R. D.; FREITAS, L. S. Características da carcaça de vacas de descarte de diferentes grupos genéticos terminadas em confinamento com distintos pesos. Revista Brasileira de Zootecnia, Viçosa, MG, v. 34, n. 3, p. 915-925, 2005.

LAWRIE, R. A. Ciência da carne. 6. ed. Porto Alegre: Artmed, 2005. $384 \mathrm{p}$.

LEÃO, J. P. Consumo, desempenho e características de carcaça e da carne de vacas e novilhos alimentados com glicerol. 2011. Dissertação (Mestrado em Ciência Animal Tropical) - Universidade Federal do Tocantins, Araguaína.

LICITRA, G.; HERNANDEZ, T. M.; VAN SOEST, P. J. Standardization of procedures for nitrogen fractionation of ruminant feeds. Animal Feed Science and Technology, Philadelphia, v. 57, n. 4, p. 347-358, 1996.

MACH, N.; BACH, A.; DEVANT, M. Effects of crude glycerin supplementation on performance and meat quality of Holstein bulls fed high-concentrate diets. Journal of Animal Science, Champaign, v. 87, n. 2, p. 632-638, 2009.

MENEZES, L. F. G.; RESTLE, J.; VAZ, F. N.; BRONDANI, I. L.; ALVES FILHO, D. C.; KUSS, F.; SILVEIRA, M. F.; AMARAL, G. A. Composição física da carcaça e qualidade da carne de novilhos de gerações avançadas do cruzamento alternado entre as raças charolês e nelore, terminados em confinamento. Revista Brasileira de Zootecnia, Viçosa, MG, v. 34, n. 3, p. 946956, 2005.

MÜLLER, L. Normas para avaliação de carcaça e concurso de carcaças de novilhos. 2. ed. Santa Maria: Universidade Federal de Santa Maria, 1987. 31 p.

Técnicas para determinar la composición de la canal. Memória de la associación latinoamericana de producción animal. Guadalajara: Alpa, 1973. 75 p.

NATIONAL RESEARCH COUNCIL - NRC. Nutrients requirements of beef cattle. 7. ed. Washington, D.C.: 1996. $242 \mathrm{p}$.

PARSONS, G. L.; SHELOR, M. K.; DROUILLARD, J. S. Performance and carcass traits of finishing heifers fed crude glycerin. Journal of Animal Science, Champaign, v. 87, n. 2, p. 653-657, 2009.

PASCOAL, L. L.; LOBATO, J. F. P.; RESTLE, J.; VAZ, R. Z.; VAZ, F. N. Meat yield of culled cow and steer carcasses. Revista Brasileira de Zootecnia, Viçosa, MG, v. 38, n. 11, p. 2230-2237, 2009. 
PASCOAL, L. L.; LOBATO, J. F. P.; RESTLE, J.; VAZ, F. N.; VAZ, R. Z.; MENEZES, L. F. G. Beef cuts yield of steer carcasses graded according to conformation and weight. Revista Brasileira de Zootecnia, Viçosa, MG, v. 39, n. 6, p. 1363-1371, 2010.

PEROBELLI, Z. V.; MULLER, L.; RESTLE, J. Estudo da qualidade das carcaças e da carne de vacas de descarte de dois grupos genéticos. Ciência Rural, Santa Maria, v. 24, n. 3, p. 613-616, 1994.

PETHICK, D. W.; HARPER, G. S.; ODDY, V. H. Growth, development and nutritional manipulation of marbling in cattle: a review. Australian Journal of Experimental Agriculture, Collingwood, v. 44, n. 7, p. 705-715, 2004.

RESTLE, J.; BRONDANI, I. L.; BERNARDES, R. A. C. O novilho superprecoce. In: RESTLE, J. (Ed.). Confinamento, pastagens e suplementação para produção de bovinos de corte. Santa Maria: Universidade Federal de Santa Maria, 1999. p. 191-214.

RESTLE, J.; KEPLIN, L. A. S.; VAZ, F. N.; MULLER, L. Qualidade da carne de novilhos Charolês confinados e abatidos com diferentes pesos. Ciência Rural, Santa Maria, v. 26, n. 3, p. 463-466, 1996.

RESTLE, J.; VAZ, F. N.; ROSO, C.; OLIVEIRA, A. N.; CERDOTES, L.; MENESES, L. F. G. Desempenho e características da carcaça de vacas de diferentes grupos genéticos em pastagem cultivada com suplementação energética. Revista Brasileira de Zootecnia, Viçosa, MG, v. 30, n. 6, p. 1813-1823, 2001.
VAN SOEST, P. J. Collaborative study of acid detergent fiber and lignin. Journal of the Association of Official Analytical Chemists, Washington, v. 56, p. 81-784, 1973.

VAN SOEST, P. J.; ROBERTTSON, J. B.; LEWIS, B. A. Methods for dietary fiber, neutral detergent fiber, and nonstarch polysaccharides in relation to animal nutrition, Journal of Dairy Science, Madison, v. 74, n. 10, p. 35833597, 1991.

VAZ, F. N.; RESTLE, J.; ARBOITTE, M. Z.; PASCOAL, L. L.; FATURI, C.; JONER, G. Fatores relacionados ao rendimento de carcaça de novilhos ou novilhas superjovens, terminados em pastagem cultivada. Ciência Animal Brasileira, Goiânia, v. 11, n. 1, p. 53-61, 2010.

VAZ, F. N.; RESTLE, J.; QUADROS, A. R. B.; PASCOAL, L. L.; SANCHEZ, L. M. B.; ROSA, J. R. P.; MENESES, L. F. G. Características da carcaça e da carne de novilhos e de vacas de descarte hereford, terminados em confinamento. Revista Brasileira de Zootecnia, Viçosa, MG, v. 31, n. 3, p. 1501-1510, 2002a.

WEISS, W. P. Method estimates available energy value for ruminants. Feedstuffs, United States of America, v. 9, p. 13-14, 1993. 